\title{
INVESTMENT REVIEW IN CANADA WE CAN DO BETTER
}

\author{
Lawrence L. Herman (C) \\ Cassels Brock \& Blackwell LLP
}

\section{SUMMARY}

Although the Investment Canada Act (ICA) is often criticized for leaving investors and the public in the dark on government decisions regarding proposed foreign investments in Canada, nothing in the Conservative government's platform suggests that the ICA's basic framework will be changed. Moreover, there is no evidence that the ICA or the review process has limited foreign investment in Canada since the Act came into force. However, the legislation should be made more open and predictable, both for the application of the net benefit test and for determinations of national security issues. When a foreign acquisition is approved or rejected, the Industry Minister should be required to issue public reasons. Where investment approvals are given subject to undertakings, the general outlines should be made public. More transparency and public disclosure will make foreign investors confident the system is fair, objective and free from bias, bolstering Canada's reputation as a fine place to invest. 


\section{INTRODUCTION}

With the election of a Conservative majority government in May 2011, renewed attention will be paid to improving Canada's foreign investment review laws. While little was said about this during the election, the Conservatives are committed to making changes - to both the Investment Canada Act (ICA) itself and to "sectoral" foreign ownership restrictions under other pieces of legislation.

This initiative stems in part from the public controversy surrounding BHP Billiton's attempted takeover of Potash Corporation in 2010. Following the government's rejection of the BHP bid in November, Prime Minister Stephen Harper said he would refer the whole issue of the ICA and reviews of foreign direct investment (FDI) to the House of Commons Industry Committee for examination. That work was just getting started in 2011 when the election was called. The committee will resume its efforts in the fall.

Adding fuel to the foreign investment controversy was the proposed trans-Atlantic merger of the TSX Group and the London Stock Exchange in 2011. While that merger eventually collapsed, it stimulated renewed debate over the impact of foreign investments and the "hollowing out" of Canada's corporate head offices resulting from these kinds of takeovers.

That debate isn't going to subside any time soon. With the trend to globalization of capital markets and the growing influence of sovereign wealth funds (SWFs) and state-owned enterprises (SOEs), Canada's approach to reviewing large corporate takeovers will remain among the most challenging for the Harper government in the months ahead.

Given this context, the following paper presents some ideas for the government and for the Commons committee to consider over the next weeks and months as they grapple with these issues. The overall conclusion is not that we should scrap the present regime - since some kind of foreign ownership limitations are considered to be in Canada's interest - but rather that much can be done to improve the system, to make it less secretive, more transparent, more predictable and more in line with Canada's generally liberal trade and investment policy.

\section{A MENU OF ISSUES}

While the Investment Canada Act was only intermittently on the radar screen over the years, attention to its famous "net benefit" test came up after a series of rapidly concluded foreign takeovers of large swaths of Canadian industry in the first part of the century. ${ }^{l}$ Renewed focus on the net benefit issue occurred after the Conservative government's rejection of the takeover of the geospatial division of MacDonald Dettwiler \& Associates (MDA) by Alliant Techsystems, an American company, in 2007. Controversy then erupted in force with BHP Billiton’s $\$ 38.6$ billion hostile takeover bid for Potash Corporation in 2010.

1 As examples: Brazilian Vale Corporation's acquisition of Inco Ltd.; Swiss-based Xtrata Inc.'s acquisition of Falconbridge Corp.; the acquisition by foreign steel producers of Stelco Inc., Algoma Inc., Dofasco Inc. and IPSCO Inc., all in the period between 2004 and 2008. 
The result in the Potash Corporation case, as is well known, was the decision by Minister of Industry Tony Clement that the bid failed to satisfy the net benefit test. In his public statement, Clement said, "I can confirm that I have sent a notice to BHP Billiton indicating that, at this time, I am not satisfied that the proposed transaction is likely to be of net benefit to Canada. I came to this decision after a careful and rigorous review of the proposed transaction."2

Under the statute, BHP Billiton had 30 days to make any additional representations and submit any renewed undertakings to meet the government's concerns. Since BHP did not take this final step, no reasons for Clement's decision have been issued. In the event, BHP packed its bag and went home, leaving behind a fierce debate about the merits of Canadian foreign investment policy. ${ }^{3}$ As noted above, the debate boiled over during the ill-fated TSX-LSE merger. ${ }^{4}$

Some experts have contended that Canada should consider doing away with foreign investment review as currently constituted. ${ }^{5}$ With federal government approvals of hundreds of foreign takeovers of broad swaths of Canadian industry over the years, plus Canada's ongoing requirement for investment capital, ${ }^{6}$ the question is whether Canada needs a generic law that reviews foreign investments in a horizontal manner, as opposed to individual pieces of legislation that restrict foreign ownership in especially sensitive sectors such as banking, telecommunications, culture and the like. Why go beyond this?

The blue-ribbon Competition Policy Review Panel (CPRP), appointed by the federal government in 2007 to examine Canada's international competitiveness, looked at these issues. In its clear and eminently straightforward 2008 report, $^{7}$ the CPRP rejected the idea of eliminating investment review or radically reducing the scope of the ICA as some suggested. As found by the panel, "[t]he ICA has not been an obstacle to direct foreign investment" over its years of operation and, as confirmed by a Conference Board report, "when the actual practices regarding foreign investment are taken into account, the impact of Canadian government intervention is not materially different from that of other industrialized countries."

2 “Industry Minister Tony Clement rejects PotashCorp takeover bid by BHP," Canadian Press, 3 November 2010 at http://www.globalsaskatoon.com; "Canada Blocks BHP's Purchase of Potash,” New York Times, 3 November 2010.

3 The drama behind the rejection of the BHP bid is too extensive to cover here. Briefly, much of it was the result of the carefully reasoned case advanced by the Premier of Saskatchewan, Brad Wall, who argued that BHP's acquisition would put the company in an overwhelmingly dominant position in Canada's potash industry, one that would have a detrimental impact on the province's resource base and its future tax revenue stream. The opposition gathered steam, with many prominent Western Canadian industry leaders and politicians supporting the Saskatchewan government's position.

4 Among the countless leading newspaper articles, see: "Banks seek ways to block TMX deal," Globe and MailReport on Business, 5 May 2011; "Maple Group goes hostile after TMX rejects bid," Globe and Mail - Report on Business, 26 May 2011.

5 Among those arguing for a much-reduced role for ICA reviews, see: Krzepkowski, M. and Mintz, J. "Canada's Foreign Direct Investment Challenge," Vol. 3 School of Public Policy Research Papers (University of Calgary), October 2010: www.policyschool.ca.

6 Together with the takeovers of the steel, nickel and aluminum industries referred to above, other examples include: the US $\$ 2.3$ billion investment by Abu Dhabi-controlled International Petroleum Investment Co. (IPIC) in Nova Corp; China Investment Corporation's US \$1.5 billion purchase of a substantial voting interest in Teck Resources; various investments by Abu Dhabi SOEs in the oil producing sector in western Canada.

7 Compete to Win, Final Report, Competition Policy Review Panel (PWGS Canada, June 2008); http://www.ic.gc.ca/eic/site/cprp-gepmc.nsf/eg/h_00040.html. The panel was chaired by L. R. (Red) Wilson, an eminent Canadian business executive, and included a number of well-known and respected experts on financial matters and competition policy.

8 Ibid., p. 29. 
So, instead of calling for an end to Canada's investment review system or a wholesale rewriting of the ICA, the CPRP offered recommendations on ways to improve the regime, to streamline it and make it more transparent and predictable while remaining consistent both with Canadian interests and objectives as well as with the policies of like-minded countries (in the OECD and beyond) that have foreign investment review mechanisms of their own. Several of the panel's recommendations were incorporated in amendments to the ICA in 2009. ${ }^{9}$ Others are still under consideration. This article looks at these and at some other ideas for improving the ICA that have been floating around in policy circles.

What emerges from this examination is that the process of Canada's investment review regime remains too opaque, too discretionary and too secretive, with only perfunctory public explanation, as has been the case over most of the 25 years of the ICA's operation. This has added to perceptions that the review process is arbitrary and politicized and thereby tarnishes Canada's reputation as a capital-friendly host country.

While these criticisms were somewhat muted in the long period of pro forma takeover approvals, increased investment activity by SOEs and SWFs in the last decade or so in conjunction with the high-profile rejections in the MDA and Potash Corporation cases, have led to intensified criticisms over the lack of public explanation and disclosure in Canada's review process. ${ }^{10}$ The fact is that the process is opaque and cloaked in secrecy, leaving Canadians and foreign investors alike in the dark about what factors lead to a given decision either for or against an acquisition. Surely we can do better.

\section{INVESTMENT REVIEW — AN EVOLVING STORY}

Canada's foreign investment review system began life under the Foreign Investment Review Act (FIRA) enacted during former prime minister Pierre Trudeau's Liberal government in the 1970s. Former prime minister Brian Mulroney's government transformed FIRA into the present ICA in 1985. The objective was to make the system more business friendly, moving from investment review to investment promotion, arguably from discouraging foreign capital to encouraging it - but with carefully drawn carve-outs for sensitive sectors and with the requirement that foreign takeovers over certain thresholds had to meet the famous "net benefit" test to be approved. ${ }^{11}$

9 Enacted as Part 13 of the Budget Implementation Act 2009, S.C. 2009, c. 2.

10 Adding fuel to the discussion is the federal government's controversial litigation against US Steel for failing to live up to the company's ICA commitments in getting federal approval for its takeover of Stelco Inc. US Steel has since closed most of Stelco's Hilton Works operations in Hamilton and put several hundred people out of work. The federal government is suing US Steel for breach of its undertaking to maintain those operations as a going concern, although details of those undertakings are not public. "Court clears way for Canada suit vs U.S. Steel," Reuters, 27 May 2011: http://www.reuters.com/article/2011/05/27/ussteel-canada-id.

11 There have been numerous articles outlining this history. Among the many that provide a useful review, see: Hale, G., "The Dog That Hasn't Barked: The Political Economy of Contemporary Debates on Canadian Foreign Investment Policies,” 41:3 Canadian Journal of Political Science (September 2008) 719. 
The new Investment Canada regime sailed along, with only intermittent controversy, for about 20 years. ${ }^{12}$ Even with the decision to deny the Alliant takeover of MDA, business discussion was relatively contained. But when BHP launched its $\$ 38.6$ billion bid to acquire Potash Corporation, the size of the deal, its industry-wide ramifications and the intense opposition by the Saskatchewan government raised the pitch of debate by many decibels. ${ }^{13}$

When the BHP bid was rejected, there were inferences that the Harper government was cozying up to Saskatchewan to improve the Conservative Party's electoral prospects in the province. Some in business circles took the position that the federal government should have backed away from interfering in the bid altogether, that this was a market-driven matter for shareholders and not for governments..$^{14}$

The idea of scrapping the investment review system altogether was rejected by the Review Panel, as noted previously, and there has been no indication that the present Conservative government will move in this direction, leading to the conclusion that the basic ICA policy and structure will remain intact in the years to come. The more pertinent challenge is to root out much of the secrecy surrounding investment reviews, to improve the system beyond the legislated changes in 2009, to make it more contemporary, more open, more certain and less subject to real or perceived influences of a short-term political nature. This will go a long, long way to assuage concerns that Canada's system is arbitrary, politicised and unfriendly to foreign capital.

\section{THE CRUX OF THE MATTER}

It's the net benefit test. That test is now applied to acquisitions of businesses exceeding an enterprise value set at $\$ 312$ million for 2011, rising to $\$ 1$ billion over the next four years. There is a perception that the test is arbitrary and unacceptably open-ended. In fact, that is not entirely so. Section 20 of the ICA contains a fair description of the factors that an investor has to show, in positive terms, to satisfy the test:

(a) the effect of the investment on the level and nature of economic activity in Canada, including, without limiting the generality of the foregoing, the effect on employment, on resource processing, on the utilization of parts, components and services produced in Canada and on exports from Canada;

(b) the degree and significance of participation by Canadians in the Canadian business or new Canadian business and in any industry or industries in Canada of which the Canadian business or new Canadian business forms or would form a part;

12 From 1985 to 2008, the federal government never blocked a foreign takeover under the ICA, approving approximately 11,214 foreign acquisitions that were notified under the requirements of the legislation. However, in the recent period, growing concern in business circles emerged over the increased extent and long-term ramifications of these takeovers. See Hale, G. op cit., pp. 734-741.

13 The reasons in support for rejecting the bid were set out in a speech that Wall delivered to the Economic Club of Canada in Toronto on 28 October 2010. In it, he explained the reasons for the province's opposition, including potential job losses and revenue declines and the "strategic importance" of potash as a key resource in high global demand to the province and to Canada at large. "Three Provinces Back Premier in Potash Fight," http://www.globalsaskatoon.com; "Premier Brad Wall Continues to Battle," Financial Post, 29 October 2010.

14 Corcoran, Terence, "Let BHP Buy Potash Corporation - Foreign Investment is the Lifeblood of the Global Mining Industry," Financial Post, 14 September 2010. 
(c) the effect of the investment on productivity, industrial efficiency, technological development, product innovation and product variety in Canada;

(d) the effect of the investment on competition within any industry or industries in Canada;

(e) the compatibility of the investment with national industrial, economic and cultural policies, taking into consideration industrial, economic and cultural policy objectives enunciated by the government or legislature of any province likely to be significantly affected by the investment; and

(f) the contribution of the investment to Canada's ability to compete in world markets

So, contrary to the assertions that the net benefit test is a subjective one and purely in the eye of the beholder - meaning the federal cabinet - the reality is that there are broadly objective factors set out in the statute, not adequately defined or sufficiently precise but nonetheless generally stated as legal criteria. The task is to make those factors much better defined and more specific and less arbitrary and open-ended.

The statement by Clement at the time that he would soon be providing "some general principles for future investments in our county" $" 15$ is a pretty vague commitment and does little to satisfy the concerns over the elastic criteria under section 20. In any case, no such "principles" have yet been issued. Press reports suggest that they will be coming out sometime during the summer of 2011, depending on how quickly the new Conservative government sets its investment policy agenda.

\section{WELCOME CHANGES IN 2008-2009}

In its 2008 report, the Review Panel had offered several recommendations for improving the net benefit test. It noted, "In the fast-moving world of modern business, where significant investment decisions are made on a global basis, regulatory clarity and administrative efficiency are among the significant factors considered by foreign investors. As such, we believe that a key objective of the changes to the ICA should be to improve the transparency, predictability and timeliness of decision making in the review process." 16

Some of these, but not all, were adopted in the 2009 amendments to the ICA as part of Bill C-10. Two that were not followed were the recommendations to remove the net benefit test entirely and to replace it with a "contrary-to-Canada's-national-interest" test. The panel had also recommended reversing the onus in applying the test so that the Industry Minister would have to demonstrate that a proposed investment would not be in Canada's national interest; that recommendation wasn't followed either. ${ }^{17}$

\footnotetext{
15 Minister Clement's press conference, 14 November 2010, reported by Greg Quinn in Bloomberg, 15 November 2010: www.bloomberg.com. In his statement on the net benefit test, Clement said, "I can confirm that I have sent a notice to BHP Billiton indicating that, at this time, I am not satisfied that the proposed transaction is likely to be of net benefit to Canada. I came to this decision after a careful and rigorous review of the proposed transaction.” BHP Billiton had 30 days to make any additional representations and submit any undertakings in response. Since BHP did not take this final step, no reasons for Clement's decision have been issued.

16 Compete to Win, supra, p. 33.

17 For a good summary of those parts of the Review Panel's recommendations that found their way into the 2009 amendments, see: Walker, S., "Amending the Investment Canada Act: An Assessment of the Government's Response to the Wilson Report," (2009) Canadian Competition Record 30.
} 
All of this supports the conclusion that the net benefit test will remain in Canadian law in the foreseeable future and that the onus will continue to remain on foreign investors to discharge the burden of meeting the section 20 criteria. While a majority Conservative government doesn't foreclose more radical changes, nothing in statements made by Harper or Conservative cabinet ministers during the election and nothing in the 2011 Conservative election platform indicates plans to change these two basic ingredients.

The central point, then, is that we need to work within these parameters, to open up the system with a careful balancing of public disclosure, on the one hand, and the protection of commercially sensitive and market-confidential information on the other. With a bit of effort, such a balance can be achieved. The advantage would be that, together with providing a more consistent policy framework, increased public disclosure of the main elements for or against a given acquisition will help immeasurably in rebutting allegations of political expediency in takeover review decisions.

This article suggests some directions in this regard.

\section{FILL IN THE GAPS}

The Competition Policy Review Panel recommended increased use of guidelines and other advisory materials to demystify the investment review process. ${ }^{18}$ This author agrees with that. One could start by filling in the lacunae in the section 20 factors listed above. For example, paragraph (a) refers to the "effect of the investment on the level and nature of economic activity in Canada." What does this mean? How is "economic activity" measured? Is it regional or must it be national in scope? Clearly, something more is needed. New regulations could set down some concrete and predictable criteria in measuring these effects.

Similarly, paragraph (c), referring to the effect of the proposed investment on "productivity, industrial efficiency, technological development (and) product variety" leaves many points unanswered. What metrics are to be applied? How do we measure "productivity," "efficiency" and "technological development"? Not that cast-in-stone criteria are needed. But there is clearly a requirement for something more than what is currently in the statute.

The same goes for paragraph (d) referring to the effect of the proposed investment on competition in Canada. And then there's the requirement in paragraph (e) that speaks of the "compatibility of the investment with national industrial, economic and cultural policies." These are pretty open-ended concepts. They need to be fenced in.

It's obvious that in these and indeed in all of the six categories in section 20 , there is a need for greater precision, consistency and predictability through promulgation of additional regulations, rules or guidelines on their application "principles" in Clement's terminology. This will reduce real or perceived arbitrariness and help eliminate some of the criticisms attending the MDA and, particularly, the BHP takeover cases.

18 Compete to Win, supra, p. 33. 
It should be noted here that while not all of the Review Panel's recommendation were included in Bill C-10, the 2009 amendments did follow several of them. Together with raising the threshold for review, ${ }^{19}$ the statute now provides for the publication of annual reports on the administration of the ICA. This is a small but important advance toward openness and transparency. ${ }^{20}$ However, much more could be done.

\section{ROOT OUT SECRECY}

Together with the problem of inadequate and incomplete public criteria is that ICA approvals and rejections themselves are shrouded in mystery. The Industry Minister has far-reaching discretion in making these decisions, most of which is outside the public eye. No public details are provided in applications for approvals of reviewable investments. The reasons for ministerial approvals or rejections are kept totally confidential. When undertakings are given to meet net benefit requirements, only the barest public information is provided. The only regular dissemination of public information on takeover issues by Investment Canada is the name of the applicant, the date of the application and a general description of the target business. ${ }^{2 l}$ All of this fuels the perception that the system is politicized.

Under the changes introduced in Bill C-10, the Minister is now required to provide reasons when a reviewable investment in rejected and "may" provide reasons when he or she decides that the investment meets the net benefit test. However, there is a major shortcoming in that nothing in the amendment requires that those reasons be made public. ${ }^{22}$ So far, none have.

Recognizing the need for protecting corporate confidentiality and the equity markets when publicly traded companies are involved, is it right that all aspects of a foreign investment proposal be kept under wraps? Should all elements in an approval or a rejection by the Minister be blocked from public disclosure? When undertakings are accepted from the acquiring enterprise as being in the public interest, does it make policy sense should these be kept totally secret? In the case of the latter, would it not be consistent with the public interest to establish some means of monitoring those undertakings in a public manner?

19 Including eliminating the low threshold of $\$ 5$ million in book value for "sensitive sectors" of uranium production, transportation and non-federally regulated financial services - but retaining the lower threshold for cultural industries.

20 Subsection 38.1 of the Act requires the Director of Investments to submit a report to the Industry Minister on the administration of the Act - other than for the national security provisions in part IV.1. The report must then be made available to the public. The first such report on the cultural industry aspect of the Act (from April 1, 2009 to March 31, 2010) can be found at: http//www.pch.gc.ca. Apart from providing statistical data and a monthly listing of acquisition approvals, no comprehensive report has yet been issued by the Industry Minister on the overall operation of the Investment Canada Act: www. http://www.ic.gc.ca/eic/site/ica-lic.nsf/eng.

21 http://www.ic.gc.ca/eic/site/ica-lic.nsf/eng/lk-31011.html.

22 Section 23.1 says that the Minister "shall provide reasons" when he or she is not satisfied that the investment is likely to be of net benefit to Canada and "may provide reasons" when an investment is approved. Nothing requires either of these decisions to be made public, however. 
There are other statutes in other areas where commercial confidentiality is balanced with the need for transparency and public disclosure and where documents are summarized or carefully redacted for this purpose. ${ }^{23}$ Those systems should be looked at with the objective of building something similar into the investment review process, including the publication of undertakings given by the acquiring enterprise.

\section{"STRATEGIC ASSETS" — THE NEW MANTRA}

During the Potash Corporation controversy, the Saskatchewan government and its supporters argued that the mineral has some sort of "strategic" value to the country at large. Before this, few would have ever conceived of potash having strategic significance. In turning down the BHP bid, Clement said he was not satisfied the net benefit test had been met, but there was no reference to so-called "strategic" considerations. Nevertheless, questions have been asked about whether some new concept had crept into the lexicon of Canadian investment review policy. Has this become a new and unwritten part of the net benefit test? What could possibly determine if a particular resource or a particular corporation was "strategic"?

These are reasonable questions. But they're chasing the wrong issue. Trying to define when or how a given sector or asset can be deemed "strategic" is of doubtful merit. Moreover, nothing in Wall's statements in the Potash Corporation case suggested that investment review policy should address so-called "strategic" values per se. Rather, the Saskatchewan position was that in applying the net benefit test, the existence of a major, internationally critical resource that has a direct bearing on economic activity in an entire region of the country could not be ignored.

In reality, section 20 of the ICA already embraces the concept of strategic interests. Paragraph (e) refers to "the compatibility of the [proposed] investment with national industrial, economic and cultural policies" taking into consideration the industrial, economic and cultural policy objectives enunciated "by the government or any legislature of any province likely to be significantly affected by the investment." Paragraph (f) refers to the "contribution of the investment to Canada's ability to compete in world markets." Implicit in these criteria is the notion of the effect of the investment on a critical (strategic) asset or resource. ${ }^{24}$

So the point is not to try to define the term "strategic," an elusive and intensely frustrating exercise. Rather, clarifying through a set of public guidelines when a proposed investment will be compatible with national policies and enhance Canada's international competitiveness, in and of itself, will take care of the "strategic" issue. Providing public reasons explaining why a particular bid fails to satisfy these factors will indicate the public interests involved without having to define the term or to list strategic assets or sectors.

23 In the case of trade remedy inquiries under the Special Import Measures Act, both the CBSA and the CITT have a process for filing of redacted documents on the public record, allowing stakeholders to have access to the basic elements in the materials without disclosure of sensitive commercial information.

24 As well, in response to the criticism that the federal government was responding to mere regional or local concerns in rejecting the BHP bid, it is to be noted that paragraph (e) of section 20 of the ICA refers to the compatibility of the investment with both national economic policies, taking into account policy objectives "enunciated by the government or legislature of any province likely to be significantly affected by the investment." 
The more appropriate response, then, is first to follow through with guidelines on the net benefit test, as the Industry Minister has promised and, second, to change the current laws respecting confidentiality in the review process. Some of this could be accomplished through regulation and the issuance of rules and guidelines short of statutory changes. Because the current version of the ICA prevents any disclosure of privileged information, there is a need for statutory amendments to ease this blanket prohibition. ${ }^{25}$ The bottom line is that the cloaking of all information in a reviewable acquisition needs to be lifted.

\section{STATE-OWNED ENTERPRISES, NATIONAL SECURITY AND ALL THAT}

In the last decade or so, the investment activities of SOEs and SWFs have emerged as a significant challenge for host governments, including Canada. ${ }^{26}$ To address some of these concerns, a list of factors applicable to SOE investments were issued by Industry Canada in $2007 .{ }^{27}$ These include the degree of state control, corporate governance, transparency, shareholder treatment (where those exist), independence of board members as well as whether the acquired Canadian business will continue to be operated on a commercial basis. On the commercial front, the factors include whether the acquired entity will continue programs of innovation, research and development and whether there will be the appropriate level of capital expenditures to maintain the Canadian business "in a globally competitive position."

While the national security dimension has been painted by some as a disguised way of protecting Canadian industries from takeovers, in fact there are serious public interest issues when SOEs and SWFs enter the market. ${ }^{28}$ These kinds of state-backed enterprises have recently been eying critical sectors of the Canadian economy (resources, technology, transportation, aeronautics). As state enterprises, the concern is that they don't or won't follow commercial considerations but will respond to political direction from the home country, whose interests may be inimical to those of Canada.

The omission of some form of national security safeguard had been considered a glaring gap in Canada's investment review system for a number of years. After debate in policy circles and in Parliament, Bill C-10 added a full-scope national security review as Part IV.1 of the ICA in 2009. The addition of Part IV.1 at long last aligned Canada's regulatory climate with that of the US, the UK, Australia, France and Germany. ${ }^{29}$

\footnotetext{
25 Section 36 of the ICA prevents any and all disclosure of "all information" with respect of an investment, implemented or proposed, by a non-Canadian to establish or acquire a Canadian business by virtually any manner of investment whatsoever.

26 See: VanderMeulen, J. and Trebilcock, M., "Canada's Policy Response to Foreign Sovereign Investment: Operationalizing National Security Exceptions,” 47 Canadian Business Law Journal 392 (June 2009)

27 Guidelines - Investment by State-Owned Enterprises - Net Benefit Assessment, Industry Canada: http://www.ic.gc/eic/site/ica-lic.nsf/eng/lk00064.html.

${ }^{28}$ VanderMeulen, J. and Trebilcock, M., op. cit., p. 394.

${ }^{29}$ VanderMeulen, J. and Trebilcock, M., supra, p. 412.
} 
It should be noted at this juncture that Canada's international treaty obligations recognize the "national security exception" as a legitimate tool when it comes to screening foreign investments. For example, the investment provisions of NAFTA are subject to the national security exceptions modelled after those contained in the WTO Agreement. ${ }^{30}$ So are Canada's bilateral foreign investment protection agreements (or FIPAs).

Part IV.1 of the ICA involves a multi-tiered process, starting with mandatory consultations with the Minister of Public Safety if the Industry Minister "has reasonable grounds" to believe that an investment by a non-Canadian could be "injurious" to national security. If the Minister arrives at the opinion that the proposed investment could indeed be injurious, an order-incouncil is needed to submit the investment to a full-scope security review. The foreign investor must be given notice of its right to make representations to the government and be given a "reasonable opportunity" to do so.

If the Minister concludes that the proposed investment would still be injurious to national security, he or she can recommend to the federal cabinet (technically, the Governor in Council) that steps be taken to disallow the investment or, alternatively, to allow it subject to conditions. The federal cabinet then can issue an order based on these recommendations.

To date, there have been no reported instances of investments being disallowed, or even reviewed, on national security grounds. That being said, there are deficiencies in Part IV.1 that require improvement, clarifying terminology, enhanced transparency, certainty and predictability. The most obvious is the absence of any details in the legislation as to the meaning of "national security" and what constitutes conditions of injury for Canada. ${ }^{31}$ This is a serious omission.

Some have argued in favour of adding a definition of the term to the statute. ${ }^{32}$ This may not be the best approach, however. As in the case of "strategic" assets referred to earlier, it would be nigh impossible to encapsulate the meaning of "national security" in a concise, workable and consistently applied definition. In addition, there is concern, as expressed in the US, that once a definition is adopted by statute, it both reduces the government's flexibility in addressing security issues in specific cases and, potentially, opens the system up to endless litigation. ${ }^{33}$

30 NAFTA Article 2102 states that "nothing in this Agreement shall be construed . . . to prevent any Party from taking any actions it considers necessary for the protection of its essential security interests."

31 Section 25.1 of the ICA simply refers to cases where there is concern that an investment may be "injurious to national security" and nothing more. The National Security Review of Investments Regulations, SOR/2009-271, deal with the process of review and nothing more. They provide no elucidation of the factors that apply to a national security case.

32 See comments in Melnitzer, Julius, “Cash Rules," Lexpert, October 2009, p. 85.

33 VanderMeulen, J. and Trebilcock, M., op. cit., p. 416. 
The better approach would be to remove the uncertainty with a set of public criteria, even in a non-exhaustive list, that would add the needed content to Part IV.1, much like in the analogous Exon-Florio Act and related legislation in the US. ${ }^{34}$ These need not be cast in stone or constrain the federal government unnecessarily in its decision-making. But they should at least provide greater clarity regarding the elements that will be taken into account in assessing these important national security concerns.

\section{CONCLUSIONS}

Foreign investment reviews will continue to be on the front burner in Canada in the days to come, as foreign capital seeks places to invest and as the global marketplace continues its relentless march. How Canada balances an open foreign investment policy with the objectives of ensuring net economic benefit to the country and meeting national security concerns will continue to be a major policy challenge.

The framework and architecture of the Investment Canada Act are not likely to be changed in the foreseeable future. Nor has there been a demonstrated need to make wholesale changes to the legislation. There is no evidence that the ICA or the review process has hindered FDI in Canada over the decades since the Act came into force.

Rather, the task ahead is to recalibrate the legislation to make the process more open and predictable, both for the application of the net benefit test and for determinations of national security issues. This can be done in several ways:

First, the Minister should be required to issue public reasons for approving or disapproving a foreign acquisition on the basis of net benefit. It would seem possible to apply that same idea, in a more restrictive manner, where national security issues are involved. Where net benefit approvals are given subject to undertakings, the content of these should be made public and metrics provided so as to monitor the fulfilment of these obligations.

There is a legitimate requirement to protect commercial confidentiality and sensitive national security issues in such a process. That can be accomplished, as in other models, where sensitive corporate information or security matters are protected from disclosure through use of public summaries or redacted documentation.

\footnotetext{
34 These factors are found in s. 721 of the US Defense Production Act of 1950 as amended by the Foreign Investment and National Security Act of 2007 (50 USC \$2170). The US Treasuring Department has published guidelines on the application of these factors by the Committee on Foreign Investment in the United States (CFIUS) and by the President in considering the Committee's Recommendations: Guidelines Concerning the National Security Review Conducted by the Committee on Foreign Investment in the United States, Vol.73 Fed. Reg. 74567 (8 December 2008).

There are several useful reference papers explaining the US process. See, for example, Jackson, James K., "The Exon-Florio National Security Test for Foreign Investment" CRS Report for Congress, 23 February 2006; Lalonde, C., "Dubai or Not Dubai?: A Review of Foreign Investment and Acquisition Laws in the U.S. and Canada," (2008) 41 Vand. J. Transnat'l L. 1475.
} 
Second, there is, and has been for many years, a need for detailed rules, guidelines and criteria for applying the net benefit test, similar to what was recently issued by Industry Canada in the case of the SOEs. The same is true for reviews based on national security concerns. While the existing legislation contains the basic framework, the structure requires additional content. The absence of this is regrettable and should be remedied as soon as possible.

These changes will eliminate perceptions of politicization in the review process. More transparency and public disclosure of ministerial decision-making will lead to more consistency, as foreign investors will know the hurdles they have to meet. The changes made to the Investment Canada Act in 2009 are not enough. More effort is needed to add clarity, certainty and predictability to the investment review process. These changes will add confidence that the system is depoliticized and reassure foreign investors that Canada is and always will be open for business.

\section{About the Author}

Lawrence L. Herman, B.A., LL.B., is a graduate of the University of Toronto Law Faculty (1969) and a member of the Saskatchewan and Ontario bars. He was in the Canadian Foreign Service in the 1970's in a variety of posts, including at the United Nations in Geneva. Mr. Herman concentrates on international trade and international business transactions in his law practice with Cassels Brock \& Blackwell LLP, Toronto. He sits on the Market Access Advisory Group (MAAG) of the Canadian Foreign Affairs and International Trade Department.

Mr. Herman has been chair of the Trade Policy Committee of the Canadian Manufacturers and Exporters and is on the Executive Board of the Canada-U.S. Law Institute; the International Affairs Committee of the Canadian Chamber of Commerce; the C.D. Howe Institute; and several other business and government policy organizations. He is Vice-Chair of Jazz-FM.91, a publicly-funded radio station in Toronto.

Mr. Herman was Director of the Task Force on Energy Trade and Investment Rules of the World Energy Council in 2007-2010. He was an op-ed columnist on international trade and business for the Financial Post (Toronto) from 1993 to 1998 and continues as a frequent newspaper and television commentator on international law and business issues. Together with numerous academic articles in legal and policy journals, Mr. Herman has authored three text-books: Canadian Trade Remedy Law \& Practice (1997); Canadian Trade Law (2008); Export Controls \& Economic Sanctions (2010). 


\section{ABOUT THIS PUBLICATION}

The School of Public Policy Research Papers provide in-depth, evidence-based assessments and recommendations on a range of public policy issues. Research Papers are put through a stringent peer review process prior to being made available to academics, policy makers, the media and the public at large. Views expressed in The School of Public Policy Research Papers are the opinions of the author(s) and do not necessarily represent the view of The School of Public Policy.

\section{OUR MANDATE}

The University of Calgary is home to scholars in 16 faculties (offering more than 80 academic programs) and 36 Research Institutes and Centres including The School of Public Policy. Under the direction of Jack Mintz, Palmer Chair in Public Policy, and supported by more than 100 academics and researchers, the work of The School of Public Policy and its students contributes to a more meaningful and informed public debate on fiscal, social, energy, environmental and international issues to improve Canada's and Alberta's economic and social performance.

The School of Public Policy achieves its objectives through fostering ongoing partnerships with federal, provincial, state and municipal governments, industry associations, NGOs, and leading academic institutions internationally. Foreign Investment Advisory Committee of the World Bank, International Monetary Fund, Finance Canada, Department of Foreign Affairs and International Trade Canada, and Government of Alberta, are just some of the partners already engaged with the School's activities.

For those in government, The School of Public Policy helps to build capacity and assists in the training of public servants through degree and non-degree programs that are critical for an effective public service in Canada. For those outside of the public sector, its programs enhance the effectiveness of public policy, providing a better understanding of the objectives and limitations faced by governments in the application of legislation.

\section{DISTRIBUTION}

Our publications are available online at www.policyschool.ca.

\section{DISCLAIMER}

The opinions expressed in these publications are the authors' alone and therefore do not necessarily reflect the opinions of the supporters, staff, or boards of The School of Public Policy.

\section{COPYRIGHT}

Copyright (C) 2011 by The School of Public Policy.

All rights reserved. No part of this publication may be reproduced in any manner whatsoever without written permission except in the case of brief passages quoted in critical articles and reviews.

\section{ISSN}

1919-112x SPP Research Papers (Print)

1919-1138 SPP Research Papers (Online)

\section{DATE OF ISSUE}

September 2011

\section{MEDIA INQUIRIES AND INFORMATION}

For media inquiries, please contact Morten Paulsen at 403-453-0062.

Our web site, www.policyschool.ca, contains more information about The School's events, publications, and staff.

\section{DEVELOPMENT}

For information about contributing to The School of Public Policy, please contact Candice Naylen by telephone at 403-210-7099 or by e-mail at cnaylen@ucalgary.ca.

\section{EDITOR}

Timothy Giannuzzi 


\section{RECENT PUBLICATIONS BY THE SCHOOL OF PUBLIC POLICY}

ENVIRONMENTAL BENEFITS OF USING WIND GENERATION TO POWER PLUG-IN HYBRID ELECTRIC VEHICLES http:// policyschool.ucalgary.ca/files/ publicpolicy/enviro\%20hybrid\%20wind\%20energy.pdf

Mahdi Hajian, Monishaa Manickavasagam, William D. Rosehart and Hamidreza Zareipour | August 2011

A FRESH START ON IMPROVING ECONOMIC COMPETITIVENESS AND PERIMETER SECURITY

http:// policyschool.ucalgary.ca/files/public policy/dburney.pdf

Derek H. Burney | August 2011

PIIGS “g” US?

http:// policyschool.ucalgary.ca/files/publicpolicy/US\%20debt\%20crisis.pdf

Stephen R. Richardson | July 2011

RHETORIC AND REALITIES: WHAT INDEPENDENCE OF THE BAR REQUIRES OF LAWYER REGULATION http:// policyschool.ucalgary.ca/files/publicpolicy/A_Woolley_lawregulat_c.pdf

Alice Woolley | June 2011

TAX IMPACT OF BC'S HST DEBATE ON INVESTMENT AND COMPETITIVENESS

http:/ / policyschool.ucalgary.ca/files/public policy/tax\%20impact\%20BCHST\%20communique\%20c.pdf Jack Mintz | May 2011

SMALL BUSINESS TAXATION: REVAMPING INCENTIVES TO ENCOURAGE GROWTH

http:/ / policyschool.ucalgary.ca/files/publicpolicy/mintzchen\%20small\%20business\%20tax\%20c.pdf Duanjie Chen \& Jack Mintz | May 2011

IS THIS THE END OF THE TORY DYNASTY? THE WILDROSE ALLIANCE IN ALBERTA POLITICS http:// policyschool.ucalgary.ca/files/publicpolicy/wildrose\%20online\%20final3.pdf Anthony M. Sayers \& David K. Stewart | May 2011

CANADA'S WORLD CAN GET A LOT BIGGER: THE GROUP OF 20, GLOBAL GOVERNANCE AND SECURITY http:// policyschool.ucalgary.ca/files/ publicpolicy/G20\%20Heinbecker.pdf

Paul Heinbecker | May 2011

CAN THE G-20 SAVE THE ENVIRONMENT? POTENTIAL IMPACT OF THE G-20 ON INTERNATIONAL ENVIRONMENT POLICY

http:// policyschool.ucalgary.ca/files/publicpolicy/G20\%20.pdf

Barry Carin | April 2011

THE IMPACT OF SALES TAX REFORM ON ONTARIO CONSUMERS:

A FIRST LOOK AT THE EVIDENCE

http:// policyschool.ucalgary.ca/files/publicpolicy/ontario\%20sales\%20tax\%20reform4.pdf Michael Smart | March 2011

CANADA'S TAX COMPETITIVENESS RANKING: MOVING TO THE AVERAGE BUT BIASED AGAINST SERVICES http:/ / policyschool.ucalgary.ca/files/ publicpolicy/2010tax\%20comp\%20rank\%20online.pdf Jack Mintz \& Duanjie Chen | February 2011

FEDERAL-PROVINCIAL BUSINESS TAX REFORMS: A GROWTH AGENDA WITH COMPETITIVE RATES AND A NEUTRAL TREATMENT OF BUSINESS ACTIVITIES

http:/ / policyschool.ucalgary.ca/files/ publicpolicy/fed\%20prov\%20tax\%20reform\%201a.pdf Jack Mintz \& Duanjie Chen | January 2011 